Maurer School of Law: Indiana University

Digital Repository @ Maurer Law

1981

\title{
Middlemen of the Law: An Ethnographic Inquiry into the English Legal Profession
}

John Flood

Indiana University School of Law

Follow this and additional works at: https://www.repository.law.indiana.edu/facpub

Part of the Comparative and Foreign Law Commons, and the Legal Profession Commons

\section{Recommended Citation}

Flood, John, "Middlemen of the Law: An Ethnographic Inquiry into the English Legal Profession" (1981). Articles by Maurer Faculty. 1834.

https://www.repository.law.indiana.edu/facpub/1834

This Article is brought to you for free and open access by the Faculty Scholarship at Digital Repository @ Maurer Law. It has been accepted for inclusion in Articles by Maurer Faculty by an authorized administrator of Digital Repository @ Maurer Law. For more information, please contact rvaughan@indiana.edu. 


\title{
Middlemen of the Law: An Ethnographic Inquiry into the English Legal Profession
}

\author{
John Flood
}

\begin{abstract}
The accomplishments of empirical research are often presented in a context that fails to show the process by which the results came about. This article examines the problems, hitches, and struggles encountered in a research project carried out on the English bar. And emphasis is given to the difficulty of tackling hitherto unexplored occupations that have had a long history of resisting research.
\end{abstract}

\section{INTRODUCTION}

This article is about how research is done: it is not intended to present the results of the research. That is the subject of another paper and book. The account will, I hope, serve to illustrate some of the hazards and risks that a researcher has to contend with during the process of empirical research. ${ }^{1}$

I undertook the research for a graduate degree in sociolegal studies at the School of Law in the University of Warwick, England. My choice of topic-Barristers' Clerks-was one that emerged from my interest in the legal profession and legal culture. Barristers' clerks are a small but highly

John Flood is a Visiting Fellow, Northwestern University School of Law, and Affiliated Scholar, American Bar Foundation. LL.B., 1975, London School of Economics; LL.M., 1978, University of Warwick; LL.M., 1980, Yale Law School.

This article will also appear in a revised version in Robin Luckham, ed., Law and Social Enquiry: Case Studies of Research (New York and Uppsala: Scandinavian Institute of African Studies, Uppsala; International Legal Center, New York (forthcoming)).

I am very grateful to the following people who generously gave their help and criticism: William L. Twining, Yash P. Ghai, Robin Luckham, Barbara Harrell-Bond, Luke C. Harris, John P. Heinz, Spencer L. Kimball, Robert Stevens, Louis B. Potter, and Antonia Pledger-Flood. And, of course, without the encouraging help of the barristers' clerks the study would not have existed.

1. A note on the meaning of "ethnographic" is in order here. Harold C. Conklin, the Yale anthropologist, defines an ethnographer as:

an anthropologist who attempts-at least in part of his professional work-to record and describe the culturally significant behaviors of a particular society. Ideally, this description, an ethnography, requires a long period of intimate study and residence in a small, well-defined community, knowledge of the spoken language, and the employment of a wide range of observational techniques including prolonged face-to-face contacts with members of the local group, direct participation in some of tht group's activities, and a greater emphasis on intensive work with informants than on the use of documentary or survey data. Used nonspecifically, ethnography refers to the discipline concerned with producing such cultural descriptions.

See Harold C. Conklin, Ethnography, in 5 David L. Sills, ed., International Encyclopedia of the Social Sciences 172-73 (New York: Macmillan \& Free Press, 1968). 
important part of the English legal profession. They are the link by which barristers and solicitors come together.

Barristers and solicitors do similar work, such as advising, drafting, negotiating, and advocacy, but under different conditions. Solicitors administer primary legal care to clients, calling in a barrister either if specialist attention is required or if the case is to go to trial. Clients are not permitted to have direct access to barristers without instructing a solicitor. ${ }^{2}$ There are more than 34,000 solicitors and almost 4,400 barristers practicing. ${ }^{3}$ Solicitors generally practice in partnerships, they have a monopoly over conveyancing work, which is very lucrative, ${ }^{4}$ and they have only limited rights of audience in some of the lower courts. Barristers, however, are solo practitioners, although they join together in groups known as chambers to share costs but not profits. They have a monopoly over the rights of audience in the higher courts and so tend to congregate in London where most High Court matters are heard. In addition, barristers are not allowed to communicate with clients directly but only through a solicitor-hence the barrister's clerk is the conduit between the two sides of the legal profession.

A person who wishes to join the legal profession must decide, while in law school, to join either an Inn and become a barrister, or the Law Society and become a solicitor. A student cannot do both. From this time, usually during the second year of law school, ${ }^{5}$ the student barrister will start to keep terms, that is, eating dinners in hall. ${ }^{6}$ After law school a year must be spent in postgraduate education acquiring practical skills such as advocacy training.

The next step for a fledgling barrister is finding. a pupillage ${ }^{7}$ and, more difficult, a tenancy in chambers. ${ }^{8}$ If successful in both endeavors, the

2. See Brian Abel-Smith \& Robert Stevens, Lawyers and the Courts: A Sociological Study of the English Legal System 1750-1965, at 222, 453 (Cambridge, Mass.: Harvard University Press, 1967).

3. 1 Royal Commission on Legal Services, Final Report, Cmnd. No. 7648, at 24 table 2.3 (London: Her Majesty's Stationery Office, 1979) [hereinafter cited as Benson Report].

4. Id., vol. 2 , at $489,\{16.105$.

5. In England and Wales, unlike in the United States, law is a first-degree subject. See 1 Benson Report, supra note 3, at $609, \uparrow 38.13$.

6. In order to qualify to be called to the bar, a student must ordinarily eat 36 dinners at the hall of his Inn. Nowadays, eating dinners rarely adds to the student's education, but it is a necessary chore. The origins of this ritual lie in the Middle Ages, when the Inns of Court were responsible for the education of lawyers. See 1 Michael Zander, Lawyers and the Public Interest: A Study in Restrictive Practices (London: Weidenfeld \& Nicolson, 1968), and 1 Benson Report, supra note 3, at 641, 13949.

7. Pupillage is a 12-month unpaid apprenticeship undertaken at the close of the academic and postgraduate vocational training. Any barrister who has been called to the bar for a minimum of five years may take on a pupil. The pupil reads his pupilmaster's papers, follows him to court, and occasionally does some drafting for the pupiimaster. See infra note 29. See also Robert Hazell, Pupillage, in Robert Hazell, ed., The Bar on Trial (New York: Quartet, dist. in U.S. by Horizon Press, 1978).

8. W. W. Boulton, A Guide to Conduct and Etiquette at the Bar of England and Wales 58 (6th ed. London: Butterworths, 1975), says: "[A] barrister must not practice unless he is a member of 
barrister will rely almost entirely on the clerk to build him or her a practice. This means the barrister will spend the early years of practice doing small cases (small criminal matters, traffic offenses, landlord and tenant disputes, and the like) and drafting pleadings and other documents. Much of this work will be sent to the chambers by solicitors the day before trial, or even on the day the case is heard. Occasionally, a barrister will walk into the clerks' room to be told that there is a case to be dealt with in half an hour. Thus, the barrister has very little control, if any, over the progress of his or her career; it all depends on the barrister's clerk.

Essentially, the barrister's clerk is the middleman, or mediator, between the diverse interests of the legal system, namely, barristers, solicitors, judges, list officers, ${ }^{9}$ and occasionally the client upon whom the system depends for its stimulus. Although these groups are discrete, they are interdependent. But their interdependence does not prevent them from pressing divergent demands that somehow must be resolved into a common aim in order for the legal process to function reasonably smoothly. How is this resolution effected? By the clerk-and in so doing he assumes different roles to satisfy his and those others' demands.

Broadly, there are three such roles: counselor, negotiator, and fixer. ${ }^{10}$ Perhaps the most important of these is the role of fixer, as the others are variations of that central character-the fixer.

Two further, but interrelated, points should be mentioned before I return to my story: they are the questions of allegiance and loyalty and of remuneration. The clerk's title tells us that the clerk works for the barrister, ${ }^{11}$ but having described the clerk as a middleman, how do we know to whose interests he is loyal? The answers are found first in the history and socialization of the barrister's clerk and second in the form of the clerk's remuneration, which is a percentage commission of the barrister's gross fee. This commission not only binds him to the barrister but also distances him by conferring on him the role of agent with connotations of

professional chambers" and has "the services of the clerk who is the clerk of the chambers and the use of the chambers' administration and facilities to the extent necessary for the proper conduct of his practice" (note omitted). At present the average number of barristers per set of chambers is 14 . These would typically include barristers ranging in seniority from Queen's Counsel to newly admitted juniors. (See 1 Benson Report, supra note 3, at 453 table 33.6.)

9. List of ficers are civil servants employed by the courts to arrange the schedules of cases to be tried. They negotiate with barristers' clerks to find the most convenient date for counsel, expert witnesses, etc., to attend the hearing. In London, clerks attend these negotiations daily, and as a consequence of their close working arrangements with list officers, clerks spend substantial amounts of time "cultivating" list officers.

10. My conception of fixer is based upon Jeremy Boissevain's characterization of a broker whom he describes as "a professional manipulator of people and information who brings about communication for profit." See Jeremy Boissevain, Friends of Friends: Networks, Manipulators and Coalitions 198 (Oxford: Basil Blackwell, 1974).

11. See Boulton, supra note 8, and see infra note 42. 
autonomy. As a consequence, the clerk's loyalties incline to the barrister group as opposed to the others.

\section{The BegINNING}

My search through literary sources did not prove to be of much benefit because so little had been written about clerks. Those authors who had taken an interest in clerks, such as Zander, Johnstone and Hopson, and Abel-Smith and Stevens, provided little or no information on how they acquired their data. ${ }^{12}$

I checked biographies of lawyers and judges, but that type of memoir concentrates on the cases of, rather than the life of, the lawyer. Luckily, one of my supervisors discovered an autobiography of a barrister's clerk, ${ }^{13}$ which conveyed a colorful impression of legal life in the $1920 \mathrm{~s}$ and 1930s. This book gave me some information about clerks on which to base my early investigations.

Few official sources mentioned barristers' clerks. ${ }^{14}$ For example, the Beeching Commission on Assizes and Quarter Sessions received evidence from a larger number of parties involved with the administration and use of the courts except, curiously, barristers' clerks. In answer to the question Why not? the Lord Chancellor's Office said:

On reflection, I rather share your sense of surprise that the Beeching Report contains nothing about the part played by barristers' clerks in the administration of the system and, in particular, in making best use of barristers' time. I can assure you that the Royal Commission had their role very

12. Zander, Lawyers and the Public Interest, supra note 6 (also now see his Legal Services for the Community (London: Temple Smith, 1978)); Quintin Johnstone \&Dan Hopson, Jr., Lawyers and Their Work: An Analysis of the Legal Profession in the United States and England (Indianapolis: Bobbs-Merrill, 1967); Abel-Smith \& Stevens, Lawyers and the Courts, supra note 2; and id., In Search of Justice: Society and the Legal System (London: Allen Lane, Penguin Press, 1968).

13. A. E. Bowker, Behind the Bar (2d ed. London: Staples Press, 1951). Also see his A Lifetime with the Law (London: W. H. Allen, 1961). Another rare memoire is Sydney Aylett, Under the Wigs: The Memoires of a Legal King Maker (London: Eyre Methuen, 1978).

14. At the time of the research, two government commissions had received evidence from the Barristers' Clerks' Association (B.C.A.), viz., First Interim Report of the Committee on County Court Procedures, Cmd. No. 7648 (1948); Final Report of the Committee on Supreme Court Practice and Procedure, Cmd. No. 8878 (London: Her Majesty's Stationery Office, 1953). Later the B.C.A. submitted evidence to the Royal Commission on Legal Services. The following reports are from commissions and committees that one would have thought would have taken evidence from the B.C.A. but did not were: Report of the Interdepartmental Committee on the Business of the Criminal Courts, Cmnd. No. 1289 (London: Her Majesty's Stationery Office, 1961); Royal Commission on Assizes and Quarter Sessions, 1966-69, Cmnd. No. 4153 (London: Her Majesty's Stationery Office, 1969) [hereinafter cited as Beeching Commission Report]; Monopolies Commission, A Report on the General Effect on the Public Interest of Certain Restrictive Practices So Far as They Prevail in Relation to the Supply of Professional Services, Cmnd. No. 4463 (London: Her Majesty's Stationery Office, 1970) [hereinafter cited as Monopolies Commission Report]; Report of the Committee on Legal Education, Cmnd. No. 4595 (London: Her Majesty's Stationery Office, 1971); Report of the Committee on the Distribution of Criminal Business, Cmnd. No. 6323 (London: Her Majesty's Stationery Office, 1975); Monopolies and Mergers Commission Report on the Two-Counsel Rule, H.C. 512 (London: Her Majesty's Stationery Office, 1976); Commission Report on Restrictions on Advertising by Barristers, H.C. 559 (London: Her Majesty's Stationery Office, 1976). 
much in mind, and you will see a passing reference to this in evidence quoted at the end of paragraph 81 of the Report. ${ }^{15}$

Paragraph 81 contained an extract of the evidence submitted by the Clerk of Assize for the North-Eastern Circuit criticizing the inefficiency of the peripatetic Assizes:

[The arguments] are levelled at the [Assize] system (if it can be called a system) which by its nature prevents an orderly pattern from ever emerging. The consequences are that solicitors, witnesses and others never know when they may be required, and barristers' clerks quite rightly take advantage of the lack of organisation to further their own ends. ${ }^{16}$

A reading of the Monopolies Commission report on professional services, ${ }^{17}$ however, produced an interesting strand of inquiry. In the appendix to the report, comparisons were drawn between the bars of England, Scotland, and Northern Ireland. Of these only the English bar had adopted the chambers system. The other two bars appeared to manage not only without chambers but also without clerks. Attracted by the idea of including a comparative aspect of my work, I wrote to the Secretary of the Northern Ireland Bar Council but received no reply. Obtaining information from the Faculty of Advocates in Edinburgh, however, was slightly more problematic because of the cultural separation between the Scottish and the English, especially in the legal professions. My supervisor, through his professional contacts, discovered to whom I should write: namely, "the Clerk to the Faculty of Advocates." And here I made a blunder. I misinterpreted the title, thinking it, perhaps, to be a Scottish equivalent to an English barrister's clerk, which was curious in light of the Monopolies Commission report's statement that none existed. I wrote inquiring about the pattern of the clerk's career and so forth in Scotland and was answered in no uncertain terms:

I was interested to hear of your research . . . and have little doubt that comparison with the profession in other countries might be interesting to you. I think, however, it is of the first importance that you should appreciate that the Scottish legal system is separate, distinct, and in no sense a variant of the English legal system. The proper method of studying it is to assume that it is different until you have received information to suggest that it is the same. While there are obvious identities in the substantive law, there is almost no similarity in matters of procedure and organization of the profession. If you think of Scotland merely as a variant you will err exceedingly and wholly misunderstand the position.

. . . You enquire "what services do you provide for the members of the Faculty", but as this comes at the end of a sentence concerning Advocates'

15. Personal communication from A. D. M. Oulton of the Lord Chancellor's Office.

16. Beeching Commission Report, supra note 14, at 39.

17. Monopolies Commission Report, supra note 14. 
Clerks perhaps I should explain first that I am not an Advocate's Clerk. The use of similar titles may be confusing. The Faculty has five annually elected officers, elected from amongst the practising Advocates, and I am one of these. As Clerk of Faculty, or, in English, Honorary Secretary of the Scottish Bar, I am responsible for the day to day management . . . . ${ }^{18}$

Thus I learned to be somewhat more cautious when delving into areas where my ignorance was total.

The only productive official source was the 1953 report on Supreme Court practice, ${ }^{19}$ in which evidence had been taken from barristers' clerks.

During this preliminary stage certain criticisms were aimed at my proposal of doing a field study of barristers' clerks. The main one was that I might be denied the access necessary for the success of the study. As an alternative, I could couch the terms of the research in the theory of professionalism and professionalization. I was reluctant to follow this course, but I realized the necessity of contingency measures and started my reading in the subject. ${ }^{20}$

\section{AcCess Plans}

It may sound a simple question, but how was $I$ to reach the clerks? That is, I knew barristers' clerks were situated in the same areas as barristers, but I did not know whom to contact.

Most occupational groups, especially those in the professional stratum, are represented by some form of association or body. Now, I was aware that the barristers' clerks had formed one, as Abel-Smith and Stevens acknowledged the assistance given by the Barristers' Clerks' Association (B.C.A.) and, moreover, referred to its annual reports. ${ }^{21}$ One possible solution to my problem would have been to ask the Senate of the Inns of Court and Bar. I resisted this line of attack because I thought I should try to avoid being "contaminated" through any connection with the bar. Instead I sent inquiries to two legal journals, the Law Society Gazette and the New Law Journal, and to Professor Abel-Smith at the London School of Economics. The editor of the Gazette replied, giving me the name and address of the Barristers' Clerks' Association's secretary and telling me: "I have already spoken to him about your letter and he is prepared to give you any information and help he can." I now felt that

18. Personal communication from the Clerk to the Faculty of Advocates.

19. Final Report of the Committee on Supreme Court Practice, supra note 14.

20. One of the most concise and elegant theoretical statements on professionalism is Terence $\mathrm{J}$. Johnson, Professions and Power (London: Macmillan, 1972), though it ignores the symbolic aspects of professionalism, for which see Everett C. Hughes, Men and Their Work (Glencoe, Ill.: Free Press, 1958), and Howard S. Becker, The Nature of a Profession, in his Sociological Work: Method and Substance, ch. 6 (London: Allen Lane, Penguin Press, 1970).

21. Abel-Smith \& Stevens, Lawyers and the Courts, supra note 2, at $\mathrm{x}, 239$ n. $4,410 \mathrm{nn} .4$ \& 6 . 
my approach would no longer be a total "cold canvass." Abel-Smith, on the other hand, in answer to my queries about the location and value of the B.C.A. annual reports that were untraceable in any library, could not remember much about the material and suggested that the Barristers' Clerks' Association had changed its name to the Legal Executives Association. Barristers' clerks had certainly not changed their name, and "legal executives" is the term now used by those who were formerly referred to as solicitors' managing clerks.

\section{BREAKING IN}

It was now time to enter the field; I had exhausted all other possible sources. I drafted a letter to the Secretary of the Barristers' Clerks' Association in which, among other things, I said:

I have been studying the literature on the legal profession and it appears to me that too much attention has been paid to barristers and solicitors. I wish to shift the emphasis to professions like your own, especially as they are such an important part of the legal profession. One often receives an incomplete picture of the legal profession because of this, and so I would like to redress the balance and complete the picture.

Also I included a few questions on numbers of barristers' clerks, recruitment difficulties, training, etc. Nothing contentious was mentioned at this stage.

While waiting for a reply I began to devise a schedule of questions on basic sociodemographic matters and professionalism, which could be adapted into either a mail questionnaire form or an interview format. The latter seemed more likely, for as one of my supervisors put it, "clerks see themselves as on a par with Queen's Counsel."”

In addition I discussed the project with Senior Master Jacob of the Queen's Bench Division, whose son had taught me at the London School of Economics. Although primarily a practitioner, he maintained a substantial interest in the academic aspects of law and procedure. He commented:

I think you have chosen a very interesting, important and somewhat neglected subject, namely the role of what you call the unadmitted personnel who form part of the English Legal System, which is sometimes for short called "paralegal" personnel. Very little has been done about this subject and it would be very useful for the profession as a whole and indeed the general public to know a great deal more of how the legal profession operates on these levels, which is really of fundamental importance, to the work that they do. ${ }^{22}$ 
After some weeks the secretary of the Barristers' Clerks' Association wrote offering to discuss the purpose of my research with me. The break had finally come.

The prospect of meeting a barrister's clerk made me quite nervous, so I took meticulous care over my preparations. Linked with these preparations was the interview with Senior Master Jacob, who, recognizing his influence in the legal community, allowed me to use his name as a lever in order to secure cooperation among others.

My preparations involved both positive and negative features. On the negative side I had decided that my association with Michael Zander and the London School of Economics should remain hidden to avoid presenting, however unintentionally, any witch-hunting impressions. ${ }^{23}$ On the positive side, I created a respectable outward appearance. I believe this to be of the utmost importance, and Stone confirms my beliefs:

Appearance substitutes for past and present action and, at the same time, conveys an incipience permitting others to anticipate what is about to occur. Specifically, clothing represents our action, past, present, and future, as it is established by the proposals and anticipations that occur in every social transaction. ${ }^{24}$

\section{Moreover:}

By appearing, the person announces his identity, shows his value, expresses his mood, or proposes his attitude .... In other words, when one's dress calls out in others the "same" identification of the wearer as it calls out in the wearer, we may speak of the appearance as meaningful. ${ }^{25}$

So, I cut my hair to collar length, and, because I did not own a suit, compromised by buying a jacket, trousers, and tie. I thought it sensible not to appear too similar to a clerk but definitely to remove myself as far as possible from the stereotype of a student. Subsequently, a clerk told me that my dress resembled that of a clerk in court vacation clothes.

I had never visited a barristers' chambers before. It was all strange. The chambers' entrance had two doors, an inner and outer. A list of the chambers' occupants' names was painted on the outer door. Once through, however, I found myself in a long, book-lined corridor where I could hear voices coming from the clerks' room. I introduced myself to the clerks, who were all junior clerks, and was asked to wait in the corridor. The

23. Since the early 1960s Michael Zander, professor of law at the London School of Economics and Political Science has been a critic of the English legal profession and legal system and was, in part, instrumental in bringing the Royal Commission on Legal Services into existence in 1976. He submitted over 700 pages of evidence to the commission. His most trenchant statement is found in Lawyers and the Public Interest, supra note 6.

24. Gregory P. Stone, Appearance and the Self, in Arnold M. Rose, ed., Human Behavior and Social Processes: An Interactionist Approach 86, 100 (Boston: Houghton-Mifflin, 1962) (emphasis in original).

25. Id. at 101 (emphasis in original). 
senior clerk kept me waiting for just over half an hour before he came out of his room.

"Hello, Mr. Flood. I'm sorry to have kept you waiting for so long. Do come in."

"Oh ... that's quite all right."

"Well, I've got your letter; what can I do for you?"

[I explain I want to write about the neglected aspects of the legal profession.]

"Mmm, but why barristers' clerks?"

[I further explain that believing the clerk to be of considerable importance in the legal system, I think a detailed, objective picture of the clerk should be drawn.]

"Yes, well, we need a serious study of our part of the profession. I, myself, have done some work. Each year I give some lectures to the young clerks in the Temple on the etiquette of the Bar, and in the past (it's been dropped now) I would preface my remarks with some of the history of the clerks. There isn't much, but I'm still looking. You know Michael Zander did his research here?"

"No?"

"Yes, he spent a couple of days in my clerks' room. Of course, he got it all wrong. Zander suppressed the truth and deliberately distorted what took place. Look ...."

[He showed me a passage from Zander's book:

The clerk sits at the fountain and can control the direction of the spray [i.e., the distribution of the work among the barristers]. ${ }^{26}$

"Now what really happens is this. We have two diaries, one for the senior men in chambers; see, their names are in order of call, and they are all booked up for weeks in advance. I can't move their work around. This other diary is for what I call the "tuppeny-ha'penny work." These are all the junior members of chambers, and most of them work from day to day, so I like to keep their days filled. This is the only type of work I can transfer from one member of chambers to another-the returns-because it comes into chambers at such short notice. There are times when it goes wrong. Mr. X was asked to chair an enquiry which was supposed to last only ten days: it eventually stretched to seventy days, so I had to return a lot of his work. . . . I started in the Temple as a boy before the war. I had to make the tea, carry the coal up three floors from the cellar, and, gradually, I was given more responsibility."

[He consented to tackle my questionnaire and arrange some interviews and let me know the results in due course. He was very generous with his time-he gave me nearly an hour. His manner and the style of his room (antique desk) bespoke considerable self-esteem and awareness of his own importance. The image was a little tarnished, however, by the presence of the photocopying machine in his room. My impression formed along the lines that he was not taking me quite as seriously as I had hoped.] ${ }^{27}$

Then I had a stroke of good fortune which radically altered the design

26. Zander, Lawyers and the Public Interest, supra note 6 , at 86.

27. This extract and the others following are taken from my fieldnotes. 
of the project. During a talk, a friend told me that he was on friendly terms with a first junior clerk of a set of chambers that was used by the neighborhood law center he worked for. He thought that this clerk would probably allow me to interview him. Within the next five minutes he had telephoned and arranged an interview for the next morning.

"Gordon," the junior clerk, was well dressed and in his early twenties. He was quick, almost slick in his movements and talk. In fact, he was uncomfortably close to the stereotypical East End cockney who was making good, even to the extent of dealing in the street markets. Talking with Gordon brought clerking alive for me. He conveyed the sense of urgency and tension that was inherent in the clerk's job. And he projected an idea of the camaraderie between clerks.
"How would you describe the relationship between the members of chambers and yourself?"
"It's a love-hate relationship. We need each other, but they can make my job hard. Like, we have a rule in chambers that every member must phone in at least twice a day in case we've got a brief that needs doing urgently. Right, we've got a couple of barristers who haven't been phoning in as they should and we've been losing work. Well, George [the senior clerk] has had a go at them, but it didn't do no good. One of them thought that he could decide when he wanted to phone in. In the end, George had to complain to the head of chambers, and it was brought up at the last chambers' meeting we had. Yeah, and now they're phoning in every morn- ing and every afternoon. . . .
"We tell pupils to keep quiet, watch their pupilmasters, keep out of the clerks' room, and not to use the telephone, or he'll give himself a bad name. . . .
"The busiest time of day for us is between 4 P.M. and 6:30 P.M. the phones go berserk. George sits there talking into four phones at once; he's amazing. You can't tell what it's like unless you see it. It's impossible to describe. Afterwards I go for a drink with the lads."
"Since you mentioned that I should see it in order to understand what it's like in the afternoon, do you think it might be possible for me to spend a day with you in the clerks' room just watching what goes on?"

Gordon agreed to ask his senior clerk about my request, but I was not optimistic. My friend had warned me that Gordon would speak to me but definitely would not have me as an observer in the chambers. Certainly, I did hope he would agree, as a day's observation, I believed, would activate and enliven the interview data.

When I subsequently telephoned the chambers to find out the decision, I was answered by Gordon's senior clerk. I was suddeńly in an awkward position. Should I act as though he knew of me? Should I ring off and try again until I got Gordon? Had Gordon, in fact, said anything to him? Instead I tried to play safe, and asked to speak to Gordon. The senior clerk did not pass me over immediately but had a whispered conversation 
with Gordon. Then he returned to me and, in an extremely abrupt tone, said: "I think it's me you want to speak to. If you wish to seek permission to enter my chambers, you must ask me; I am the senior clerk." I apologized profusely; then he asked me how long I would want to stay. When I suggested two or three days so I could become acquainted with the procedures of the clerks' room, he was reluctant: " Oh, I don't know about that . . . It's a bit long, we'll have to see." He asked me to give him a few days notice before I wanted to come.

To disgress for a moment: because this was my first research project I felt extremely anxious about its potential success, especially as so many variables were beyond my control. At times my doubts brought me to the stage where I wished I had taken up a piece of "safe" library research. But what became increasingly frustrating was the discrepancy between the progress of my research and the conventional accounts of research which gave the impression of having proceeded with 'ne'er a single hitch." With this in mind I began reflecting upon the irony of the fact that the most substantial piece of research anyone does is generally undertaken at the lowest level of research experience. Although it is true that this type of experience is meant to provide a training, the magnitude of its influence is such that one's whole future career can hinge on the success or failure of that particular project. Nevertheless I was commited to my study.

But my hitches were these: first, mistaking the proper identity of the clerk to the Faculty of Advocates, a minor blunder; second, my awkwardness over the telephone to the senior clerk; the third, however, was completely unexpected. It almost sounded the death knell for the entire project and also multiplied my anxieties beyond measure.

I telephoned the chambers to submit a firm date for my visit; I was careful to ask for the senior clerk. He inquired if I had read the New Statesman that day. I told him I had not. He then launched into a lengthy tirade against an article entitled: "N.C.O.'s of the Law." There was one paragraph, in particular, that had greatly upset him.

One person who felt the clerks' prejudice is a clerk herself: Mary Hickson, the clerk of the most unusual chambers in Britain, those of Lord Gifford in Lambeth. She works in an office that has a notice "Sue The Bastards!" by the door and an anti-anti-abortion poster in the window. As part of her training for clerking, she spent two months in [George's chambers]. "I learned how much I disliked the Temple and how much they don't want a woman to be a clerk. The senior clerk there just told me to go away and get married." This prejudice is exercised against women as barristers, though, says Hickson, "they think they're okay for some things like matrimonial work." 28

28. Jeremy Bugler, NCOs of the Law, 91 n.s. New Statesman, Mar. 5, 1976, at 286. 
In addition, the article referred to the criticism that the barristers' clerk's commission tended to inflate the fees charged to clients.

The senior clerk vehemently denied any bias against women; he even stated that when a new set of chambers was being established he had recommended a woman as clerk. The description of the clerks' room, including its posters, represented to him a gross violation of good taste and proper conduct. And moreover, he was worried that he might be associated with this radical style of clerking: "I certainly wouldn't have posters and a sign saying 'Sue the Bastards!' in my clerks' room." $\mathrm{He}$ also felt unjustifiably attacked over the inflation of counsel's fees and put forward the defense that certain occasions and circumstances demanded he reduce or even waive some fees. Sometimes, he said, the fault lay with solicitors who offered unnecessarily high fees to counsel: for example, one solicitor suggested a 50-pound fee for a matrimonial matter that, at best, was worth only 25 pounds.

The upshot was, however, that no barristers' clerks would allow me, or any other researcher, to enter their chambers-a total, eternal ban. I felt dizzy with shock, but my reflexes took over and for the following 20 minutes I virtually pleaded with him to change his mind about me. I pointed out the advantages, in that I would be able to present a fair and objective picture of clerking which would naturally suffer through my not having experienced the urgency and frenzy of the clerks' room. And as a final argument, I offered him the opportunity to read and criticize my writing, but without assigning any editorial control to him. To my surprise, and relief, my arguments had some effect. He began to retreat from his position and question me about the length of my stay. I answered that two or three days would be sufficient (bearing in mind his previous objections but also realizing that he might have forgotten them). Again, he raised objections over the length of my proposed stay but, greatly to my surprise, considered it short and instead suggested I extend my visit to a week, when he could take me to the Old Bailey and the Law Courts. Paradoxically, my situation had actually improved as a result of this catastrophe. It was as though he wanted me to prove the article false.

My intention was to spend a short time in these chambers and then return to the secretary of the Barristers' Clerks' Association to carry out the interviews. In short, the stint of participant-observation would supplement the interview data.

\section{IN THE FIELD}

The senior clerk suggested I arrive at his chambers at about 10 A.M. (even though he arrived at 9:30 A.M.) because "nothing happens before then." When I walked into his chambers it was obvious he had forgotten 
who I was. But after a few moments he recognized me and introduced me to his colleagues.

The chambers were a common law set. That is, between them, the barristers could tackle most legal problems except the more esoteric areas of legal practice such as patent and tax law. There were more than 20 tenants (i.e., members of the chambers), about 6 pupil barristers who could work, and 3 pupils in their first six months of pupillage. ${ }^{29}$ The staff consisted of the senior clerk, the first junior, the second junior, a typist, and a part-time accounts clerk. All of these, except the accounts clerk, occupied the same room. This room had been designed to suit the needs of the clerks, and consequently there was no truly convenient place for me.

All the clerks' tools and materials were immediately at hand. The senior and first junior clerks sat opposite each other with a trough between them which contained the solicitor-clients' ledgers. Resting on top of these were two large, red diaries-one for the senior barristers, the other for the junior-which were constantly passed between the two clerks throughout the day. Each clerk had three telephones, the most important instrument in the chambers. Behind the first junior clerk were stacked the barristers' trays in which mail and briefs awaited collection. Hence, every barrister was, in effect, forced to pass through the clerks' room every time he entered or left the chambers to check the inflow of work-so enabling the clerks to monitor their barristers' movements.

I was placed next to the senior clerk, who gave me some papers, letters, and fee notes to browse through while he worked. Since I did not want to interrupt his routine too frequently I tried to be as unobtrusive as possible. I just sat with a notebook recording conversations, answers to questions, people's movements, and my impressions. No one commented on the presence of the notebook. But in one respect I need not have worried as the clerks did not appear overburdened by their work.

The first two days in this set of chambers were, in retrospect, the most crucial days I spent in the field. During this period I realized that my project would have to undergo a fundamental alteration in focus and method, from a study based on the sociology of professions to one of ethnography and fieldwork. The clerks' behavior showed an intention to demonstrate that clerking was an esoteric practice and an honorable calling. They were keen to show me the better side of their craft, but their actions, I believe, went beyond mere showmanship. There was a genuine

29. See 1 Benson Report, supra note 3, at 610, 938.16 , "in the period between 1960 and 1970, the work of the Bar increased considerably. In the same period its numbers did not increase in the same proportion. The effect was to reverse the traditional situation and so provide a ready supply of work for newcomers to the Bar. For this reason, the Senate introduced, in 1965, the rule that no barrister should accept a brief until he had completed six months' pupillage ...." Also see id. at 619 , 938.41. 
concern that I should learn; in contrast to the secretary of the Barristers' Clerks' Association, they took me seriously. And by the end of the second day in the Temple I had been introduced to George's friends, who were tentatively prepared to support my research by accepting me into their chambers.

My decision to make this change in the research was an intuitive one. I "knew" I was going to be able to implement the scheme of research I had originally intended-a field research study of barristers' clerks without the hindrance, as I believed it, of the sociology of the professions. But one consequence of this change was a strong feeling of having been left in limbo. The successful introduction and friendly relations with the clerks gave me the confidence to attempt a field research study, but all my energies and thoughts had been directed toward interviews as the prime sources of data. Hence, the internal wranglings on how to succeed in field research, for, apart from reading a few monographs, I had had no training and worse, in order to seize the moment, I did not have time to retreat from the field and learn the proper techniques, if any. As William F. Whyte once remarked: "I did not develop [my] ideas by any strictly logical process. They dawned on me out of what I was seeing, hearing, doing-and feeling. They grew out of an effort to organize a confusing welter of experience." 30

Over the next few months the pace at which my research progressed startled me, leaving me at times quite bewildered. With George, the first senior clerk, sponsoring me, my presence was being accepted. One clerk went as far to joke that I would soon become an "honorary clerk" (probably more of a joke against me than for me). The legitimation of my position was strongly assisted by George's status among the clerks. Within his own clique there was no doubt that he was primus inter pares, and among clerks at large his reputation commanded respect and not a little envy. No one, therefore, was going to contradict explicitly his evaluation of me, but I would not know the force of his influence until I moved to another set of chambers.

In all I spent over a month at his chambers. He gave me a solid grounding in the features of the clerk's job. I was even given the opportunity to be his junior clerk when his first junior took a holiday. Neither of us discussed my active participation in the clerks' room; it just emerged naturally, for with the sudden vacancy a pair of idle hands seemed incongruous. Through answering the telephone I became aware of the closely textured relationship between the solicitor and clerk. The solicitor relied on the same voices coming over the telephone, thus ensur-

30. William Foote Whyte, Street Corner Society: The Social Structure of an Italian Slum 357 (2d ed. enl. Chicago: University of Chicago Press, 1955). 
ing the development of trust between them. My answering of the telephone could almost be interpreted as a betrayal of that trust. The voice they heard was foreign and strange, and they would demand either to know who I was or to be transferred to someone they knew.

The telephone, as I have already mentioned, is the most important tool the clerk possesses. And enormous significance is assigned to the recognition of the speakers' voices. This recognition of identities is a prerequisite for normal conversation to occur; otherwise, the natural sequences are interrupted and confusion results. ${ }^{31}$ One prominent vocal feature shared by many clerks is the London cockney accent that accentuates their East End working-class origins. One clerk has been moved to declare: "One of the greatest attributes of counsel is his diction. We clerks should emulate them. Many of us were born cockneys, but it is not necessary to thrust this fact down everybody's ears." 32 My own accent is typically standard English - the same as many solicitors' accents. So, in order to explain away this irremediable incongruity, George would refer to me as a "temporary trainee clerk," which usually satisfied the inquirers.

Through George, the first senior clerk, my project was transformed. He showed me the courts, the pubs, and the cafés where clerks and lawyers hung out. I also became associated with the Temple football team of which George was manager and trainer. Besides familiarizing me with the clerk's constituency, he also acquainted me with his opinions of other clerks, which gave me a rough and ready scale to gauge clerks by. One clerk, for instance, was considered "a great person" to drink with, but, unfortunately, he had a "hopeless set" (and he drank too much), so George never passed him any work. Another was too harsh on his barristers; they needed kinder treatment. George, however, placed himself between these two extremes-the ideal clerk.

In general, clerks do hold themselves in high esteem. They need to, in order to sell counsel to solicitors and fix fees and arrange court lists. But clerks do doubt themselves, especially their abilities to hold their chambers together. And to assuage their doubts they would frequently speculate on possible or probable schisms in other sets. Much of this kind of introspective talk would come out during the hours spent in pubs.

At this stage in the research not only the character of the relationships between clerks was beginning to emerge but also that between clerk and barrister.

"I tell you barristers need clerks because they have got no common

31. Cf. Garfinkel's experiment in disruption to display the normal techniques and rules of interaction in Harold Garfinkel, Studies in Ethnomethodology (Englewood Cliff, N.J.: Prentice-Hall, 1967).

32. Sydney G. Newland, The Barrister's Clerk 5 (London: Barristers' Clerks' Association, 1971). 
sense; and that is what a clerk's got. These barristers go to university and they get pumped full of law through one ear and their common sense comes dripping out the other side."

[This was spoken replete with gestures-fingers in at one ear and the others waving away from the other.]

"He [the barrister] has a good brain and the Lord Chief [Justice] loves him, but he is lazy: I just got to put up with it, he'll never change."

These two quotations depict the "love-hate" characteristics of the clerk-barrister relationship and are in stark contrast to the conventional wisdom:

Those who survived and found themselves selected as senior clerks had had the additional advantage of being thrown into daily constant contact with members of the Bar, men and women of erudition and ability whose professional conduct is at the highest possible level. What better University could a barrister's clerk have or desire? ${ }^{33}$

While I was in George's chambers, the secretary of the Barristers' Clerks' Association wrote to me. I had been waiting for him to complete my questionnaire. He wrote:

I suddenly remembered you yesterday, and tried to find the questionnaire I was going to fill in for you-regretfully without success. Could you kindly send me another? ... I don't know whether you saw the article in The New Statesman. I should be interested to hear your views.

Several clerks told me to have nothing to do with him, especially George, who said: "Tell him I'm looking after you now." I refused to sever all connection with him and did try to have him complete another questionnaire. But I felt more secure in not having to rely on the secretary for all my access.

The next couple of sets I visited were clerked by friends of George. They were all common law chambers (i.e., generalist, but with a bias to criminal law), and I was becoming concerned that I might be restricted to this type because the circles I moved in were basically of this kind. (However, I did, if possible, want to encounter other types, such as civil and chancery.)

\section{The Art of Taking Notes Politely}

In that first set of chambers my notebook was ever present, and I recorded everything I possibly could in it. I filled page after page while sitting in the clerks' room-conversations, movements, people, and so forth. However, there were situations when I had to abandon the notebook. I could not, for example, stand at a bar in one of the local pubs

33. Id. at 2. 
jotting down notes on a conversation I was having with a clerk at the time. Walking to, and attending, listing sessions at courts were also occasions when the notebook was put away. A researcher does not blend into his background by displaying the symbols of his craft to everyone around. The policy of recording everything was a reflection of my decision not to ask many questions of the first senior clerk, as I did not want to annoy him. I occasionally made queries, but his explanations were interrupted frequently by telephone calls.

When I transferred to the next set of chambers my method of recording data changed drastically and, to some extent, set the pattern for the future. The senior clerk there criticized me for not asking enough questions-for example: "Your ignorance [of clerking] is absolute." He disliked my sitting quietly in the clerks' room taking notes as I had done before, and both he and his junior clerk insisted that I ask questions constantly, irrespective of how busy they appeared, so I badgered them with questions. But I kept my notebook in view and recorded short notes as necessary.

During this time my dependence on the instantaneous recording of notes was diminishing, and it was possible to hold sequences of events and talk in my memory for subsequent recording. It helped me be less conspicuous. One clerk said approvingly that I listened and did not talk too much. Others would give me running commentaries on their actions throughout the day. So the journey back to my apartment on the nighttime underground train proved an excellent occasion to jot down notes.

Much of the data I collected came through the medium of gossip. Getting oneself plugged into gossip networks is an integral part of any field research. The most sensitive issue I encountered was that of the barrister's clerk's income. Zander underscored the high earnings of the clerks; ${ }^{34}$ in 1968 he quoted figures of senior clerks earning 5,000 pounds to 10,000 pounds a year; in 1976 Bugler updated the speculation to 15,000 pounds to 25,000 pounds a year. ${ }^{35}$ Nevertheless Zander admitted: "There is little hard information about the earnings of the clerks. Even the members of the Chambers frequently do not know what their clerk is earning." ${ }^{36}$ I was unable to obtain an answer to this question of earnings except in two cases. One arose from a discussion in a pub with a particularly aggressive clerk who kept hedging on the subject of money. He was teasing me, so to stop the evasion I asked him outright how much he earned. Again he was evasive, but he admitted that it was possible for clerks to be averaging 20,000 pounds a year. In the other case I accompanied a clerk on a visit to

34. Zander, Lawyers and the Public Interest, supra note 6, at 86.

35. Bugler, supra note 28.

36. Zander, Lawyers and the Public Interest, supra note 6, at 86. 
a mortgage broker when the clerk was considering buying a country cottage. The broker asked about the clerk's income, which the clerk estimated to be 17,000 pounds a year. And it is possible that that sum did not include everything. In the end I must admit I never really cracked open the shell of silence that enveloped the problem of how much barristers' clerks earned. ${ }^{37}$ In contrast to their shyness about their incomes, several clerks freely offered information about their sex lives.

There is always a problem of reliability when gossip is taken as data. In this situation the researcher is quite powerless to ask for "the truth." All one can do is test each bit of information against other informants' opinions and statements. This rough and ready form of triangulation will, at least, allow one to feel whether the information is correct or not.

\section{The Demon Drink}

At this point in the story I want to describe a problem for which I was completely unprepared.

On my first day in the Temple the senior and first junior clerks took me to a local pub and bought me two or three pints of beer. So the afternoon went by in a slight haze. The next day was a Friday, a special day, when George would meet his friends for an extended, and intensive, drinking session. It was done quite smoothly; as each clerk entered the pub he would buy a round of drinks for the others. Occasionally, it was reversed and those already in the pub would buy a round for the newcomer and others. I had between eight and ten pints of Guinness bought for me (I can't remember the exact number), and I think I may have drunk six of them. However many it was, the barman commented that it was a shame for me to leave the beer, but I couldn't drink it. I was becoming aware that fairly large amounts of drink were going to be the norm. It was a daunting prospect. During my period in the field, which was approximately eight months, my consumption of alcohol in all its forms exceeded any previous levels of intake. I was drinking regularly most lunch times and several evenings a week. Sometimes a drinking session would go through the whole night; for example, one such session lasted 12 hours. The weekends were quite valuable for me-I used them to recover.

Drinking also created other problems, such as when I was banned from a pub with two other clerks. Having drunk a substantial quantity of beer one night, we decided to gatecrash a private party in the rooms above the bar. We successfully negotiated our way in but were spotted by the landlady, who was not on the best terms with one of the clerks. She threw us out, and while we were waiting downstairs for a taxi, one of the clerks,

37. Nor did the Benson Commission; see 2 Benson Report, supra note 3, $\S 14$. 
who was southern Irish, had an argument with the head barman, who was northern Irish, over the serving of drinks after hours. The two nearly had a fight, but fortunately the taxi arrived in time. The following day we heard on the grapevine that we were banned. At first, I was afraid this would cut me off fron a profitable area of research, but the damage was not too bad, as that particular pub was already losing most of its clerks to another and the ban only served to accelerate that process. As one clerk put it: "We left a lot of beer on the deck that night." One difficulty arose, however, when later in my research some clerks decided to have a drink at lunch time and went to this pub. I had to make an excuse and duck out at the last minute to avoid any embarrassment. Two or three months after the start of the ban I was able to return to the pub.

At other times the problems were not so immediate. The night before I was due to lunch with the chairman of the B.C.A. I had had a hectic evening at a club with a clerk. Consequently, I was not at my most alert the next day and had serious doubts about whether I would appear sensible to the chairman. I concentrated hard and survived the lunch.

It could be thought (as my girlfriend did) that I was foolish to get drunk so often, but I believe my research would have suffered without my willingness to drink. A significant part of legal life revolves around the use of alcoholic drink; to have excised this part from my fieldwork would, I am certain, have only distorted the picture.

One further point should be made about drink and research. Rereading my field notes made when drunk raised some questions about how drunkenness affected the quality of my recording. First, I used to have some trouble making my notes, because after drinking I knew at what point on my homeward journey I would become incapable of writing. Second, if I did not makes notes fairly soon after the event I might forget some things. Third, there was the difficulty of actually reading the notes. Frequently the handwriting was a scrawl. I felt everything was usually there on paper, with occasional blank spots. Although I have been unable to locate any research that discusses the problems of intoxication during research (most researchers, it appears, don't drink or get intoxicated), I would strongly suspect the degree of intoxication must have some effect on the outcome. ${ }^{38}$

\section{Progressing in the Field}

Through luck I managed to switch into other types of chambers. George invited my girlfriend and me to the Barristers' Clerks Association Annual Dinner and Dance. After the meal I noticed the chairman of the

38. Cf. Bill Bottomley, in Colin Bell \& Sol Encel, eds., Inside the Whale: Ten Personal Accounts of Social Research (Pushcutters Bay, Australia: Pergamon Press, 1978), who reported similar experiences. I should also point out that the clerks did not appear adversely affected by the drink. 
B.C.A. circulating among the guests. Although I didn't know him, I introduced myself. Fortunately, he had heard about me and invited me to lunch.

He accepted my inquiry seriously, in contrast to the secretary. Moreover, I was well settled in the Temple by this time, and even if he had wanted to prevent me from doing research, I think he would have had some difficulty. Notwithstanding that, he helped me gain access to other chambers. He also provided me with the Methods Manual for Counsel's Clerks, ${ }^{39}$ a vade mecum for clerks which nobody appeared to use (it was out of date) and nobody liked (no one was prepared to revise it), and he let me have the B.C.A. annual reports, 1948 to 1976, which provided a great deal of material on the professional aspirations of clerks.

By this time I was beginning to construct a global picture of clerks. Using the Law List I calculated a figure of 300 senior clerks and speculated, adopting a ratio of two juniors to one senior, that there might be 900 clerks in toto, with a predominance of men. ${ }^{40}$ The majority of clerks were on a percentage commission, and many were receiving 10 percent, ${ }^{41}$ although the bar has begun to exert pressure on clerks to accept a reduction in the percentage from 10 percent to $7 \frac{1 / 2}{2}$ or 8 percent. A number of clerks tried to prevent this downward drift through contributing to chambers' expenses, for example, paying the salary of a junior clerk; but in some cases even this has been insufficient sacrifice. ${ }^{42}$

Most clerks entered the Temple directly from grade school and served an apprenticeship of several years with other senior clerks before obtaining their own set of chambers. Their background was mainly working class. In a few sets of chambers there was a tradition of father-to-son succession in the senior clerkship.

Women were tolerated as typists and tea ladies but were not welcomed as senior clerks. Those that succeeded, despite the obstacles, were accorded some respect. But this kind of prejudice is not peculiar to barristers' clerks; it exists throughout the bar. ${ }^{43}$

I also found some comparative materials on clerks. The chairman of

39. Barristers' Clerks' Association, Methods Manual for Counsel's Clerks (London: Barristers' Clerks' Association, 1970).

40. The Benson Commission also had difficulty in counting barristers' clerks, stating there were approximately 265 senior clerks and 325 junior clerks. See 2 Benson Report, supra note 3, $\$ 14$, \14.3 and 914.52 .

41. Id. at $\S 14$ table 14.7 .

42. A senior clerk who refused to accept a reduction in his commission was dismissed. He took the matter to an industrial tribunal for unfair dismissal. But the tribunal ruled on a preliminary point stating that barristers' clerks were self-employed contractors, not employees. Thus he could not claim for unfair dismissal. See Barristers: One Man and His Clerk, Economist, May 20, 1978, at 26.

43. See Helena Kennedy, Women at the Bar, in Hazell, supra note 7, at 148. 
the B.C.A. put me in touch with a barrister's clerk in Melbourne, Victoria, a state in Australia that contained a de facto division between barristers and solicitors. There, the clerk managed chambers of 100 barristers, as compared with the English average of 14. And he received a percentage.

Nan Wilson's doctoral thesis on the Scottish Faculty of Advocates mentioned four or five clerks in Edinburgh who clerked the entire faculty, also for a percentage..$^{44}$ But the faculty has now converted its clerks into the employees of a company, Faculty Services Ltd.

The most exotic comparison was provided by the Indian munshi, ${ }^{45}$ who appeared to be caught in an embittered conflict with his barrister, the vakil. Each of the two was continually trying to find ways of defrauding the other of his rightful dues. They were never reconciled, and the struggle was only resolved when the vakil attained the ideal of government office.

Through the chairman of the B.C.A. I gained entry to civil, chancery, and revenue chambers. Some of the original clerks I knew objected to my shifting ground into new areas. They thought there was sufficient material to be found among the clerks of common law chambers. In one way they were right, but I felt I could not deny myself, or the project, the opportunity to become familiar with lesser known aspects of clerking. As it turned out, they used to pump me for information about life in other sets; for example, they would ask: "Is it very dull in tax chambers?" Or, "What's so and so's business like?"

\section{Other Problems}

There are fundamental sets of problems: those external to the researcher and those generated by the researcher. I shall take the external problems first. I have already outlined the difficulties over access and entry. One further problem only came to my notice during the fieldwork. My status to some extent was a reflection of my credentials or lack thereof. I had started graduate work immediately after I had taken my law degree: I had not qualified as a barrister or solicitor. To the barristers' clerks this "unqualification" made me acceptable, less threatening. If I had been a qualified lawyer, the research would have been impossible: no one would have talked to me. For example, my girlfriend was studying for the bar

44. Nan Wilson, The Sociology of a Profession: The Faculty of Advocates (doctoral thesis, University of Edinburgh, 1965). And see her The Scottish Bar: The Evolution of the Faculty of Advocates in Its Historical Social Setting, 28 La. L. Rev. 235 (1968), and The Professional Community: The Edinburgh Advocates, 23 Rec. A.B. City N.Y. 174 (1968).

45. See Charles Morrison, Munshis and Their Masters: The Organization of an Occupational Relationship in the Indian Legal System, 31 J. Asian Stud. 309 (1972); and his Clerks and Clients: Paraprofessional Roles and Cultural Identities in Indian Litigation, 9 Law \& Soc'y Rev. 39 (1974). 
exam while I was doing the fieldwork, and while she was a student, clerks would call her by her first name. As soon as she was called to the bar, she became "Miss__" to them. A barrister or solicitor is someone a clerk does business with, even when they are drinking together. Being a law graduate, then, freed me from those constraints and allowed me to do the research.

There were, however, adverse reactions to my presence and criticisms about the "futility" of the study. Some clerks disliked the idea that their almost unknown occupation might be opened up to public view. They constantly emphasized the esoteric, arcane aspects of their jobs, such as the complexities of having to manage the idiosyncrasies of " 23 prima donnas," as one clerk put it.

You have to be careful dealing with barristers; you need patience, tolerance, and understanding. The moulding of a barrister is a very delicate operation. I like nothing better than to see a young man start and then go to the bench.

Our pupils don't really work until they have done 12 months with us. If you put them into court after 6 months it doesn't really do their careers any good.

I can judge a man very well now: I listen to him and I can tell if he is arrogant or got that certain something that means he will do well.

Another clerk spoke of women barristers thus:

Women are not physically or emotionally suited to the bar; they are not as robust as men. It's something to do with their glands.

They get too involved. I've got one barrister-took her on because I thought she would add a bit of glamour to the chambers. But after two years I realized my mistake. If she writes an opinion she will take 20 pages instead of 3, and I can't charge the solicitor for that.

A number of clerks concluded that because of their incommensurable individuality I would never be able to generalize about them. One clerk went further and suggested I give up this "nonsense" (i.e., my research) and write a novel about clerks instead.

Some barristers also reacted strongly to my presence in their chambers. My visit to a set of chambers was usually the result of an agreement between the senior clerk and the head of chambers; the remainder of the barristers would know of me only when they saw me in the clerks' room. For the first day or two they would not notice me and assume that I was a solicitor, or solicitor's clerk, or counsel's clerk. They would ignore me except for a casual "hello." As my visit lengthened, their curiosity would grow, and they would begin to ask: "Who's that chap?" Some thought of me as a representative of the Customs and Excise investigating barristers' Value Added Tax returns, or a spy for the Royal Commission on 
Legal Services ${ }^{46}$ and, perhaps, a spy for Michael Zander. Once a senior barrister cross-examined me:

[A large man, with strong "presence," he came into the clerks' room; I was the only occupant.]

"Who are you?"

"My name is John Flood. I'm doing some research on barristers' clerks."

"Come to my room a minute, I would like to talk to you."

[We go into his room. There are two other barristers and a pupil there.]

"Would you mind leaving us for a moment, chaps? Oh, James [the pupil], could you lend me a couple of cigarettes? ... Thanks. Sit down. Now, what exactly are you doing?'”

'I'm trying to describe what barristers' clerks do, and show what part they play in the legal system. I believe they have been unduly criticized on the basis of insubstantial evidence."

"Why are you doing this research?"

"Because I'm interested in the legal profession, and also I'm doing it for my Master's degree at Warwick University."

[The pace of his questions accelerated.]

"And whose idea was it?"

"It's mine."

"And what are your qualifications?"

"I hold a law degree."

"Where from?"

[Here, perhaps, I was stupid-I told the truth.]

"L.S.E."

"Are you anything to do with that man Zander?"

"Well ... . he did teach me once."

"You know the trouble with him, don't you-everybody knows-he's a failed barrister. So he becomes a solicitor and attacks the bar. If he got his way and we were nationalized, half or more of the bar would emigrate; we wouldn't stay here having people like him tell us what to do . . ."

[There was a knock on the door and the senior clerk entered.]

"Excuse me, sir, I was looking for John. Do you mind if I have him back, sir? We're about to go over the road to check the lists."

[I get up, gladly. I was worried how much longer my cross-examination would continue. My nerves were dancing around alarmingly; I was not used to this sort of verbal onslaught. Outside the room the clerk apologized to me.]

"I would never have let this happen if I'd been there. Don't worry about it, but he's good, isn't he?"

Problems arise, too, from the researcher's proximity to the subjects. The researcher wants to get inside the subject's mind, but how far should he agree with the subject? For example, Polsky writes:

46. The establishment of the Royal Commission on Legal Services and my fieldwork coincided. Also see note 23 supra. 
Studying a criminal in his natural setting . . . means studying him in his usual environments rather than yours, in his living quarters or streets or taverns or wherever, not in your home or your laboratory. And it means you mustn't "schedule" him, mustn't try to influence his shifting choices among his environments or interfere with his desire either for mobility or immobility. If he wants to sit in front of his TV set and drink beer and watch a ball game for a couple of hours, so do you; if he wants to walk the streets or go bar-hopping, so do you; if he wants to go to the racetrack, so do you; if he indicates (for whatever reason) that it's time for you to get lost, you get lost. ${ }^{47}$

I think I have shown how far I was prepared to go. But a related problem is that of overempathy. Research is not just a mechanical activity, it has consequences for oneself. One undergoes changes as one's experience increases. At the start of the project I was heavily influenced by Zander's view that clerks were bad for the legal profession. While doing the field research I attempted to suspend such moral judgments and maintain an objective, open-minded attitude. During the fieldwork some of the relationships developed into friendships, and for a time, I found myself becoming defensive about barristers' clerks. Both New and Johnson warn the prospective researcher against overempathizing, ${ }^{48}$ as it may distort the collection and presentation of data or, worse, prevent the researcher from ever publishing his results. My own predicament was moving toward this extreme, especially when I became a clerk.

It was a new set of chambers and I happened to be available. I enjoyed the work even though the mixture of roles caused some confusion at first. The barristers couldn't decide if I should be treated as a colleague or a clerk. As time passed, they resolved the issue in favor of me as clerk. Sometimes, when no one else was around, one would talk to me on equal terms. Nevertheless, I had to decide where my loyalties lay. And I decided in favor of my senior clerk, which meant I reported to him things that he would want to know in order to organize the barristers. The solicitors, because I saw them less frequently, tended to treat me as a clerk.

There were times when I felt like staying on and remaining a clerk. The researcher part of me still functioned, however, and each evening after work I would write up my notes. Among other things, the comments of close friends about my views, behavior, and the job made me reconsider my situation; they thought I was reneging on my commitment to study clerks because I was becoming one. To them I appeared to subscribe to the clerk's viewpoint. So I took a brief respite from the research and the

47. Ned Polsky, Hustlers, Beats and Others 135 (Chicago: Aldine Publishing Co., 1967) (emphasis in original).

48. Peter Kong-Ming New, The Personal Identification of the Interviewer, 62 Am. J. Soc. 213 (1956); John M. Johnson, Doing Field Research (New York: Free Press, 1975). 
job. A few months later I returned to those chambers and, as a favor to the senior clerk, worked in them for two weeks; but by then I realized I didn't want to be a clerk. Perhaps Madge's exhortation to the researcher demands too much of him or her: "When the heart of the observer is made to beat as the heart of any other member of the group under observation, rather than as a detached emissary from some distant laboratory, then he has earned the title of participant-observer." 49

\section{WRITING UP}

I collected masses of data that caused many a headache when I tried to place them in some order. What order?

Initially, then, I made a rough threefold division: the first part would contain introductory material, the social, demographic, historical, and geographic data, ${ }^{50}$ an account of the "methods" used, and the comparative data; the second part would focus on the relationships formed by the clerks between themselves and with others; the final part would be an examination of the organizational characteristics of clerks. The kernel of the monograph was to be the second part; and the first module would establish the setting for the ethnography of the second. The third section was included, however, for a special reason.

At the start of the project I had invested a substantial amount of energy in the sociology of professions. As the research developed, its significance and relevance, both as a form in which to situate the research and as an explanatory tool, diminished. Nevertheless, a textual analysis of the annual reports, the main fund of data for the third part, revealed a series of maneuvers by a faction within the Barristers' Clerks' Association that were designed to raise the status of barristers' clerks and restrict entry to the occupation. That is, the symbolic features of professionalism were being manipulated in order to change the face of clerking and alter the essentially individualistic orientation of clerks toward accepting the hegemony of the management committee of the B.C.A. These aspects of the theory, then, contributed to the explanation of the emergence of the B.C.A. as a significant, but effete, organization. By making a cause

49. John Madge, The Tools of Social Science:An Analytical Description of Social Science Techniques 137 (Garden City, N.Y.: Doubleday \& Co., Anchor Books, 1965).

50. As Nan Wilson pointed out, research is more easily conducted if the subjects are concentrated in a single area. See Wilson, Sociology of a Profession, supra note 44. The English Bar is not quite as compact and immobile as the Faculty of Advocates, but the majority of barristers are still to be found in the Inns of Court in London. Of the four Inns, Gray's Inn is the least densely populated, supposedly because of its great distance from the Law Courts. Lincoln's Inn houses most of the chancery lawyers. And the Temple, Inner and Middle, contains the greater part of the common law bar. I concentrated on the Temple for two reasons, namely, the officers of the Barristers' Clerks' Association were there, and it was where I was fortunate to make my initial entry. Thus the Temple was not a random choice in a statistical sense, but the fieldwork did include Lincoln's Inn and some chambers outside the Inns of Court. 
célèbre out of the sanctity of the separateness of the clerk's fee, the B.C.A. only brought forth the reaction of the bar, which was to suppress these maneuvers. The suppression was elegantly effected. The bar, with the aid of the decimalization of the currency, incorporated the separate clerk's fee into that of the barrister. Admittedly, this was mainly a change in form only, but I can only reiterate the importance of the symbolic dimension in confrontations such as these. Thus I felt the investment I made at the start of the project paid off in part.

Unfortunately, I was unable to devote sufficient time to discovering the history of the clerk. The data I collected owed more to fictional sources than to proper historical records. Part of the trouble arose from the many uses the word "clerk" was put to. Every time I came across a mention of clerks I would get excited until it became clear that it was another reference to, say, an apprentice lawyer. Hence, most of my history was speculation except, perhaps, for sources such as Charles Lamb's description of Lovel (his father), clerk to Samuel Salt KC:

He was at once [Mr. Salt KCs] clerk, his good servant, his dresser, his friend, his "flapper," his guide, stop-watch, auditor, treasurer. [Mr. Salt $\mathrm{KC}]$ did nothing without consulting Lovel, or failed in anything without expecting and fearing his admonishing. . . . He resigned his title almost to respect as a master, if $\mathrm{L}$. could ever have forgotten for a moment that he was a servant. ${ }^{51}$

My trust in the truth of this quotation increased when a senior clerk described his job: "A barrister's clerk does everything for his governor, even sewing on his fly-buttons because the typist couldn't do it, as there wasn't time to take his trousers off."

Although the work was essentially ethnographic, I did borrow some sociological concepts that lent some logical coherence to the material. In the chapter on clerks' career patterns I adopted the notion of the reference group to show the socialization process, especially in the senior clerk's role as mentor to young junior clerks.

And in the chapter on the relationship between the clerk and the barrister I found Goffman's dramaturgical perspective useful in bringing out the ambivalence within the relationship. On the one hand, there was the extreme deference shown to the barrister-for example, the clerk always addresses barristers, despite their age differences, by the term "Sir," and the barrister always calls his clerk by the clerk's first name. One senior clerk, when first entering the Temple, was given a lesson in deferential conduct by his first senior clerk as follows: "When I call someone by their name, you call them Mr. So and So; when I call someone Mr. So

51. Charles Lamb, The Old Benchers of the Inner Temple, in Essays of Elia 94, 101 (Boston: D.C. Heath \& Co., 1909). 
and So, you call them Sir; when I call someone Sir, you don't speak to them." But this explicit behavior did not reveal the true nature of the relationship. Up front it appeared as though the barrister was continually in command; however, the power arrangement backstage was the other way round. The clerks' room was the administrative hub of the chambers. Nothing entered or departed the chambers without passing through there: control of the information flow, therefore, equaled power. The distribution of work and the rate at which fees were collected were ways in which the clerk could manipulate his principals. Notwithstanding the potential for manipulation, the clerk's main goal was to secure the economic success of his chambers; thus, he did not overindulge in power games. The only exceptions to this rule occurred in the case of minorities, such as women and blacks, when on occasion a clerk's prejudices could overcome his fundamental economic sense.

The main criticism leveled at barristers' clerks is that their percentage commission compels them to extort the highest possible fee from the client. This is the essence of the arguments put forward by Zander and Abel-Smith and Stevens, ${ }^{52}$ and in my view it is wrong. It concentrates on the short term, the one-shot deal. But business is not conducted this way. Of course the clerk does consider his return, as must all wage laborers, but not to the single-minded exclusion of everything else.

Most clerks want to develop their chambers by maintaining a "good ladder." That is, they try to establish a set of chambers with a range of counsel from the mere pupil to the eminent Queen's Counsel (QC). This allows them, in theory, to meet the various demands of solicitors.

Now solicitors can be selective and pick a junior barrister from one chambers and a QC from another. And in cases demanding special expertise this is done. But a considerable amount of work for which counsel are required is routine work, and for this a solicitor will frequently depend on one or two barristers' clerks to supply the necessary counsel. As can be expected, the market evens itself out over time. Neither the clerk nor the solicitor wants violent swings in counsel's fees. Both desire consistency; and without it the clerk cannot maintain his "ladder"; he must generate a regular turnover of business. Thus charging exorbitant fees would only scare away the solicitors. And I have not seen any cartels formed in an attempt to raise fees.

Fees are fixed in various ways according to the type of work being done. Brief fees are negotiated before the case is heard (or settled). In large cases involving several barristers, QCs or juniors, the clerk of the most senior barrister will take the lead in the negotiations fixing his fee

52. See Zander, Lawyers and the Public Interest, supra note 6, and Abel-Smith \& Stevens, Lawyers and the Courts, supra note 2, and id., In Search of Justice, supra note 12. 
first. Then the other clerks will take their lead from him. Legal aid fees tend to be determined by the taxing authorities of the courts, and the clerk's role is reduced to one of making appeals against taxations if the fee is considered to be too low.

In paperwork (nonadvocacy work), such as drafting an opinion or advice, the clerk assesses the fee on completion of the work, usually by estimating the value of the time spent on the task (or the time that ought to have been spent). One clerk would take a stack of opinions one by one, read the first couple of paragraphs and then flick through to the end-occasionally commenting on the style or whether a particular point was correct or not-and pencil in the fee.

Fixing the fee is, however, easier than collecting it. Most clerks took a perverse pride in showing me their backlogs of outstanding fees. Generally they stretched back as far as three or four years, but some went back as far as ten years or more. These were lost forever. Understaffed litigation departments in solicitors' offices and fear of antagonizing solicitors by demanding fees were some of the reasons the backlogs flourished.

\section{REACTIONS TO RESEARCH}

One of the difficulties inherent in such a work as this is that once it has been written the observer's cover has been blown completely-that is, the observed are now able to read the views of the researcher. This is an extremely critical moment for the researcher, for most probably he will want to carry out further research (and most research reports emphasize, or belabor the point of, the need for further research-a kind of exemption clause), but his subjects, in effect, know what he is looking for. Moreover, if they are an oversensitive group, as are barristers' clerks, they might withold future cooperation. It depends on what kind of bargain the researcher has struck with the subjects; if he has carte blanche, then he hopes the subjects will respect his freedom; if he has, as in Douglas's terms, made an "unholy alliance," he is placed in the position of the "social investigator [who] cracks the secrecy, but buries the secrets, one by one, in a tomb of silence-as do all the professions which deal with the problems of people."ss

During the writing of the thesis I produced a working paper based on the data I had collected; basically it was a summary..$^{54}$ I circulated it to some of the clerks for their comments, but only one replied. He had

53. Everett C. Hughes (The Sociological Eye (Chicago: Aldine Publishing Co., 1970)), quoted in Jack D. Douglas, Investigative Social Research: Individualized and Team Field Research 43 (Beverly Hills, Cal.: Russell Sage, 1976).

54. John Flood, Barristers' Clerks (paper, University of Warwick, 1977) (on file at Yale Law School library). 
drafted some notes on the working paper and gave me other comments in an interview as well. In the main, he did not like my use of verbatim comments of clerks, most of which he considered "offensive to members of the bar." For example, in the case of the quotation about sewing on a barrister's fly-buttons, he would have preferred "fixing a buckle onto his breeches," something which he once did for one of his Queen's Counsel. As he put it, "I don't like fly-buttons." Perhaps his opinion of me was summarized in one of his written comments (which he meant to remove but did not): "Quoting what some clerks told him shows what a young man he is, but nevertheless makes better reading." After the interview we went to the pub for a beer. However, during our third double whiskey he began to tell me about the time when he took control of his chambers on the retirement of the previous senior clerk. His first question to the outgoing clerk was, "Have you got any shits in the chambers, [George]?" $\mathrm{He}$ then told me how he removed some barristers and replaced them with others. He did not seem to realize he was contradicting himself. But I made no bargains or "unholy alliances" with the clerks, and I never believed it was necessary to cover up or provide a public relations exercise for them.

\section{CONCLUSION}

Perhaps a conclusion is superfluous: it's all there, and there is nothing more to say. I refuse to rationalize it because it didn't happen that way. This research resulted from liberal doses of luck, alcohol, and inexperience. In substantial part, my goal was achieved: an ethnography of barristers' clerks which made some contribution toward analyzing the distribution of power between the barrister's clerk and the barrister. 